\title{
Effects of chromium piclonate and ascorbic acid supplementation on growth performance, carcass traits, blood constituents and picture of growing kids under the summer conditions
}

\author{
U. M. Abd El-Monem ${ }^{1}$, M. A. Kandeil ${ }^{2 *}$ \\ ${ }^{1}$ Department of Animal Production, Faculty of Agriculture, Zagazig University and ${ }^{2}$ Department of Biochemistry, \\ Faculty of Veterinary Medicine, Beni-Suef University, Beni-Suef, Egypt
}

\begin{abstract}
The present work was performed to study the effect of chromium piclonate and/or ascorbic acid supplementation on the performance of growing kids during hot summer season $\left(33.6^{\circ} \mathrm{C}\right.$ and $74.2 \%$ RH). A total number of twenty four weaned commercial kids were randomly distributed into four treatment groups of 6 kids per each Kids in all treatments were equal in number and had nearly similar initial body weight. The first group was fed the basal diet and served as control $(0.0$ supplementation), while the other three groups were fed diets supplemented with $75 \mathrm{mg} / \mathrm{kg} \mathrm{diet}$ chromium piclonate, $800 \mathrm{mg} / \mathrm{kg}$ diet ascorbic acid and $75 \mathrm{mg} / \mathrm{kg}$ diet chromium piclonate $+800 \mathrm{mg}$ ascorbic acid, respectively. The results obtained for growing Kids showed that the final live body weight and daily body gain were increased significantly $(P<0.05$ or 0.01$)$ during 210 and 270 days for Kids fed diets supplemented with chromium piclonate, ascorbic acid and chromium piclonate + ascorbic acid. However, the supplementation of chromium piclonate + ascorbic acid seemed to be the best significant performance. The results obtained for growing Kids showed that the daily feed intake, feed conversion, water / feed intake ratio, water/daily gain ratio were increased significantly $(\mathrm{P}<$ 0.05 or 0.01 ) during the experimental periods for Kids fed diets supplemented with chromium piclonate, ascorbic acid and chromium piclonate + ascorbic acid. The Results showed that water intake, rectum temperature and respiration rate were not significantly affected by previous treatments. The best margin was obtained in group fed on the diet supplemented with chromium piclonate + ascorbic acid. All carcass traits were increased insignificantly due to dietary chromium piclonate and/or ascorbic acid supplementation. Serum total proteins were increased significantly (P $<0.05$ ), in group three only while the cholesterol level and triglycerides decreased significantly $(\mathbf{P}<\mathbf{0 . 0 5})$ in Kids treated with chromium piclonate as compared with the control group under summer heat stress conditions. Serum albumin, globulin, urea-, creatinine, AST, WBCs, RBCs MCV, MCH and $\mathrm{Hb}$ content were insignificantly affected by chromium piclonate and /or ascorbic acid supplementation to the kids' diets. Finally, it could be concluded that supplementation of $75 \mathrm{mg}$ chromium piclonate $+800 \mathrm{mg}$ ascorbic acid / $\mathrm{kg}$ diet to the kid diets is necessary to improve the productivity, under the summer conditions.
\end{abstract}

In tropical and sub- tropical countries, climatic heat is the major constraint on animal productivity. Production and reproduction are impaired as a result to the drastic changes in biological functions caused by heat stress (Kamal et al., 1989 and Marai et al., 2006). Live body weight and gain were decreased by exposure to heat stress. Ascorbic acid, which is present in most animal cells, has numerous biochemical functions. It is essential for growth and counteracting infections caused by pathogenic bacteria and viruses. Verde and Piquer, (1986) noted that the plasma ascorbic acid concentration was significantly reduced in animals exposed to stress. In other species, supplementary ascorbic acid has been shown beneficial in reducing the effects of stress. This means that the metabolic need for ascorbic acid is increased at certain conditions. Therefore, the growth-promoting effect of ascorbic acid may be associated with the alleviation of retardation in the thyroid function, (Coates, 1984).

Abdel-Hamid, (1994) found that body weight, body weight gain, feed intake and feed conversion were improved significantly $(\mathrm{P}<0.01$ or 0.05$)$

* Corresponding author. Tel.: + 2001093322583 ;

Fax: +20 082/2327982

E-mail address:kan002003@yahoo.com 
during the summer period for growing rabbits when fed diets supplemented with ascorbic acid, also, Afify and Makled, (1995) found that the growth performance and blood components were affected significantly $(\mathrm{P}<0.05)$ with ascorbic acid supplementation at $200 \mathrm{mg} / \mathrm{kg}$ diet for bouscat rabbits till 6 months of age. Abdel-Hamid and ElAdawy, (1999) reported that the ascorbic acid supplementation at 300 or $600 \mathrm{mg} / \mathrm{kg}$ of rabbit diets improved significantly $(\mathrm{P}<0.01)$ growth performance and, economical efficiency when compared with the control. There is no information about the effect of ascorbic acid on the performance of growing kids

Chromium is one of the most important trace elements, its level must be constant in the blood, and it is responsible for maintenance of the blood glucose level (Underwood, 1977). It plays a role in the glucose tolerance, where it facilitates the attachment of insulin to its receptors, so potentiates the action of insulin (Anderson, 1987). Johnson, (1986); Moonsie-Shgeer and Mowat, (1993) reported that chromium may improve the immune response of stressed animals. Later, Kegley et al., (1997) recorded that supplemental organic chromium has markedly improved the growth rate and immune response of stressed feeder calves. Chromium piclonate decreased the total cholesterol, LDL cholesterol (Press et al., 1990). Also reduced body fat while the lean mass was increased (McCarty, 1991).

The present study was conducted to study the effect of chromium piclonate and/or ascorbic acid supplementation on the performance of growing kids, under summer heat stress conditions $\left(33.6^{\circ} \mathrm{C}\right.$ and $74.2 \% \mathrm{RH}$ ).

\section{Materials and methods}

A total number of twenty four weaned commercial kids were randomly distributed into four treatment groups of 6 kids per each. Kids in all treatments were equal in number and had nearly similar initial body weight. The first group was fed the basal diet as control (0.0 supplementation), while the other three groups were fed the basal diets supplemented with $75 \mathrm{mg}$ chromium piclonate $/ \mathrm{kg}$ diet, $800 \mathrm{mg}$ ascorbic acid / $\mathrm{kg}$ diet and $75 \mathrm{mg}$ chromium piclonate + $800 \mathrm{mg}$ ascorbic acid / $\mathrm{kg}$ diet, respectively. Animals were individually weighted at two successive days at the beginning of the experiment and then at 15 days intervals up to the end of experiment (3 months). The daily feed and water consumption were recorded and the feed efficiency was estimated.

Kids were housed in semi- open sheds allover the experimental period. All groups were fed ad libitum on a concentrate (as mixture basal diet as shown in Table 1). Rectal temperature and respiration rate were measured three times at 8.00 , 12.00 and $16.00 \mathrm{hrs}$. for one day every week, during the experimental periods. Rectal temperature was measured by inserting YSI Electronic Thermometer Model 46. Respiration rate (RR) was counted by the consistent flank movements per one minute. All measurements were taken within a range of time that did not exceed 2-3 minutes for each animal.

Table (1): Ingredients of kids' diets, chemical composition $\%$ and feeding value.

\begin{tabular}{ll}
\hline Items & \% \\
\hline Ingredients & 83.00 \\
Corn & 15.00 \\
Soya bean meal & 1.4 \\
Calcium carbonate & 0.5 \\
Sodium chloride & 0.1 \\
Minerals and vitamins & \\
& \\
Chemical composition \% & \\
Dry Matter & 90.38 \\
Crude Protein & 16.15 \\
Ether Extract & 1.92 \\
NFE & 2.28 \\
Ash & 76.10 \\
Moisture & 3.55 \\
Feed Value & \\
TDN & 55.50 \\
SV & 34.30 \\
DCP & 11.94 \\
\hline
\end{tabular}

At the end of experimental period, blood was collected from the marginal ear vein after shaving and cleaning with alcohol in less than 2 minutes into dry clean centrifuge tubes for hematological and biochemical analysis. Serum samples were separated by centrifugation at $3000 \mathrm{rpm}$ for 20 minutes and kept in a deep freezer at $-20^{\circ} \mathrm{C}$ until analysis. Total proteins (Weichselbaum, 1946), albumin (Doumos et al., 1971), urea (Fawcett and Scott, 1960), creatinine (Bord and Sirota, 1948), cholesterol (Richmond, 1973), triglycerides (Eggstein, and Kuhlmann, 1974) concentrations and AST and ALT enzyme activities (Reitman and Frankel, 1957) were estimated. Globulin values 
were obtained by subtracting the values of albumin from the corresponding values of total proteins. Five kids in each group were slaughtered for studying carcass traits. Before slaughter the kids were fasted for $12 \mathrm{hrs}$. The dressing percentage was calculated as (hot carcass weight, liver, heart and kidneys) relatively to slaughter body weight. Data obtained were statistically analyzed by using completely randomize design according to Snedecor and Cochran, (1982) by the following model: $\mathrm{Xij}=\mu+\mathrm{Ti}+\mathrm{eij}$ where, $\mu=$ general mean, $\mathrm{Ti}=$ fixed effect of the treatments $(1, \ldots \ldots, 4)$ and eij $=$ random error. The differences between experimental groups were separated by Duncan s multiple range test (Duncan, 1955).

\section{Results and discussion}

Growth performance. Data in Table 2 revealed that the growth performance of the growing kids in terms of final live body weight and daily body gain were increased significantly $(\mathrm{P}<0.05$ or 0.01 ) during 210 and 270 day age groups during all the experimental periods for Kids fed diets supplemented with chromium piclonate, ascorbic acid and chromium piclonate + ascorbic acid. However, the supplementation of chromium piclonate + ascorbic acid seemed to be the best significant performance. The previous results agree with Abdel-Hamid and El-Adawy, (1999) who found that the addition of $600 \mathrm{mg}$ of ascorbic acid increased significantly $(\mathrm{P}<0.01)$ final body weight and daily weight gain by 3.04 and $9.41 \%$ respectively, than in the control group. Also, other authors obtained the same results such as AbdelMonem, (2000) in rabbits, Shahin and Kucuk, (2001) in Japanese quails, Sahina et al., (2003); Asli et al., (2007) found the same trend in laying hens. The supplementation of calve diets with chromium piclonate increased significantly $(\mathrm{P}<0.05)$ final body weight and daily weight gain than in the control group El-Masry et al., (2001); Gaber and Abdel-Monem, (2003) in rabbits and Tahan et al., (2005) in lactating cows. The increase in growth rate and final body weight from supplemented $\mathrm{Cr}$ could be resulted from increased, nitrogen retention (Kornegay et al., 1997), incorporation and utilization of amino acids and nuclear protein synthesis (Weser and Koolman, 1969) and RNA synthesis (Okada et al., 1981). On the other hand, (Borel et al., 1984) reported that the positive increases in growth performance by using $\mathrm{Cr}$ likely attributable to the apparent effect of $\mathrm{Cr}$ on the distribution of energy between adipose and lean tissues. Moreover the improve of immunity (Mowat et al., 1993) and elevation in growth hormone level (Page et al., 1993) may play a role in improvement of growth rate and body gain.

The results obtained for growing Kids showed that the daily feed intake, feed conversion, water/ feed intake ratio, water / daily gain ratio were increased significantly $(\mathrm{P}<0.05$ or 0.01$)$ during the experimental periods for Kids fed diets supplemented with chromium piclonate, ascorbic acid and chromium piclonate + ascorbic acid (Table 2). The beneficial effects of growth, feed intake and feed conversion due to ascorbic acid supplementation may be due to that ascorbic acid helps to control the increase in body temperature and plasma corticosterone concentration. It also, protects the immune system and it has an important role in bone formation through the growth rate (Pion et al., 2004; Asli et al., 2007).

The Results showed that water intake, rectum temperature and respiration rate were not significantly affected by previous treatments. The best margin was obtained in group fed on the diet supplemented with chromium piclonate + ascorbic acid. All carcass traits were increased insignificantly due to dietary chromium piclonate and / or ascorbic acid supplementation (Table 2). Similar results were obtained by Gaber and AbdelMonem, (2003) who found that the rectum temperature and respiration rate were not significantly affected by the presence of chromium piclonate in the rabbit diets.

Carcass traits. All carcass traits studied (Dressing $\%$, Liver weight $\%$, Head weight $\%$ and the eye muscle weight $\%$ ) were increased due to using chromium piclonate and / or ascorbic acid supplementation on the kid diets Table (3). Similar results were obtained by Pion et al., (2004) who found that feeding growing swine on diets containing ascorbic acid increased the carcass and non carcass weights.

Some blood parameters and constituents. The results obtained for the blood serum of growing Kids showed that the total proteins in vitamin $\mathrm{C}$ group increased significantly $(\mathrm{P}<0.05)$, while the cholesterol and triglycerides were decreased significantly $(\mathrm{P}<0.05$ or 0.01$)$ in Kids treated with chromium piclonate as compared with the control group under summer conditions (Table 4). 
Serum albumin, globulin, urea, creatinine, AST, WBCs, RBCs $\mathrm{MCV}, \mathrm{MCH}$ and $\mathrm{Hb}$ content were insignificantly affected by chromium piclonate and /or ascorbic acid supplementation to the kids diets (Table 4).

The results seem to be like that produced by Campbell et al., (1997) who found that hematocrite, $\mathrm{Hb} \%$, RBCs count, mean corpuscular volume (MCV) and mean corpuscular hemoglobin $(\mathrm{MCH})$ were within the normal clinical ranges, but the blood platelets was increased significantly $(\mathrm{P}<0.05)$ by using chromium piclonate supplementation. Chang and Mowat, (1992) who showed that serum globulin in calves were increased with chromium piclonate supplementation; this improves the immune state of the animal. Our result was similar with that produced by Lee and Reasner, (1994); ElGharably (2000). They recorded that chromium piclonate supplementation is associated with lower serum triglycerides, also we are on the same ground with Boyd et al., (1998) who reported that chromium piclonate supplementation decreased total cholesterol and LDL.

It could be concluded that supplementation of $75 \mathrm{mg}$ chromium piclonate $+800 \mathrm{mg}$ ascorbic acid / $\mathrm{kg}$ to the kid diets is necessary to improve the productivity, under the summer conditions.

Table (2): Effect of chromium piclonate and / or ascorbic acid supplementation on growth performance, some physiological parameters and profit analysis of growing commercial kids, under summer conditions.

\begin{tabular}{|c|c|c|c|c|c|}
\hline Items & Control & Cr 75 mg/kg diet & $\begin{array}{c}\text { Vit. C } \\
800 \mathrm{mg} / \mathrm{kg} \text { diet }\end{array}$ & $\begin{array}{c}\text { Cr } 75 \mathrm{mg}+ \\
\text { Vit.C } 800 \mathrm{mg} / \mathrm{kg}\end{array}$ & Sig. \\
\hline \multicolumn{6}{|l|}{ Body weight } \\
\hline At 120 day of age & 8.4 & 9.1 & 9.0 & 8.9 & N.S \\
\hline At $Y$ l. day of age & $18.2^{\mathrm{b}}$ & $19.5^{\mathrm{ab}}$ & $20.6^{\mathrm{a}}$ & $21.9^{\mathrm{a}}$ & $*$ \\
\hline At $r v \cdot$ day of age & $25.7^{\mathrm{c}}$ & $29.9^{b}$ & $31.5^{\mathrm{ab}}$ & $33.3^{\mathrm{a}}$ & ** \\
\hline \multicolumn{6}{|l|}{ Daily gain } \\
\hline $120-210$ & $108.9^{c}$ & $115.6^{\mathrm{cb}}$ & $128.9^{b}$ & $144.4^{\mathrm{a}}$ & $* *$ \\
\hline Y). -270 & $156.7^{\mathrm{b}}$ & $173.3^{\mathrm{a}}$ & $181.7^{\mathrm{a}}$ & $190.0^{\mathrm{a}}$ & $* *$ \\
\hline $12 \cdot-270$ & $115.3^{\mathrm{b}}$ & $138.7^{\mathrm{ab}}$ & $150.0^{\mathrm{a}}$ & $162.7^{\mathrm{a}}$ & $* *$ \\
\hline Feed intake & $492.5^{b}$ & $571.8^{\mathrm{a}}$ & $590.8^{\mathrm{a}}$ & $610.9^{\mathrm{a}}$ & ** \\
\hline Feed conversion & $4.3^{\mathrm{a}}$ & $4.1^{\mathrm{ab}}$ & $3.9^{\mathrm{b}}$ & $3.8^{\mathrm{b}}$ & $*$ \\
\hline Water intake & 1037.3 & 987.5 & 1009.5 & 1005.7 & N.S \\
\hline Water/Feed intake ratio & $2.1^{\mathrm{a}}$ & $1.7^{\mathrm{b}}$ & $1.7^{\mathrm{b}}$ & $1.6^{\mathrm{b}}$ & $*$ \\
\hline Water/daily gain ratio & $9.0^{\mathrm{a}}$ & $7.1^{b}$ & $6.7^{\mathrm{b}}$ & $6.2^{\mathrm{b}}$ & $*$ \\
\hline \multicolumn{6}{|c|}{ Some physiological parameters } \\
\hline Rectum temp. & 39.9 & 39.6 & 39.9 & 39.5 & N.S \\
\hline Respiration rate & 91 & 86 & 83 & 94 & N.S \\
\hline \multicolumn{6}{|l|}{ Profit analysis } \\
\hline Feed cost & 147.6 & 171.6 & 177.2 & 183.2 & \\
\hline Return & 242.2 & 291.2 & 315.0 & 341.6 & \\
\hline Margin & 94.6 & 119.6 & 137.8 & 158.4 & \\
\hline
\end{tabular}

Price: Experimental diet $=1.0 \mathrm{LE}$ per $\mathrm{kg}$ diet, kids live body weight $=10.0 \mathrm{LE} \mathrm{per} \mathrm{kg}$, Margin per head $==$ Return from body gain - feed cost. Other head costs were assumed constant.

$\mathrm{N} \mathrm{S}=$ not significant, $*(\mathrm{p}<0.05)$ and $* *(\mathrm{p}<0.01)$. Means $\mathrm{a}, \mathrm{b}$ and $\mathrm{c}$ in the same row bearing different letters, differ significantly $(\mathrm{p}<0.05)$. 
Table (3): Effect of chromium piclonate and / or ascorbic supplementation on carcass traits of growing commercial kids under summer conditions.

\begin{tabular}{|c|c|c|c|c|}
\hline Items & Control & $\begin{array}{c}\text { Cr } 75 \text { mg/kg } \\
\text { diet }\end{array}$ & $\begin{array}{c}\text { Vit. C } \\
800 \mathrm{mg} / \mathrm{kg} \text { diet }\end{array}$ & $\begin{array}{c}\text { Cr } 75 \mathrm{mg}+\text { Vit.C } \\
800 \mathrm{mg} / \mathrm{kg}\end{array}$ \\
\hline \multicolumn{5}{|l|}{ Carcass traits } \\
\hline Dressing \% & 48.3 & 50.6 & 51.2 & 54.1 \\
\hline Liver weight $\%$ & 1.4 & 1.5 & 1.8 & 1.8 \\
\hline Head weight \% & 7.4 & 7.1 & 6.8 & 6.7 \\
\hline Eye muscle weight & 1.6 & 1.7 & 1.8 & 1.9 \\
\hline
\end{tabular}

Table (4): Effect of chromium piclonate and /or ascorbic supplementation on serum biochemical parameters and blood picture of growing commercial kids, under summer Egyptian conditions.

\begin{tabular}{lccccc}
\hline Items & Control & $\begin{array}{c}\text { Cr 75 mg/kg } \\
\text { diet }\end{array}$ & $\begin{array}{c}\text { Vit. C } \\
\mathbf{8 0 0 ~} \mathbf{~ m g / k g ~ d i e t ~}\end{array}$ & $\begin{array}{c}\text { Cr 75 mg + } \\
\text { Vit.C 800 mg/kg }\end{array}$ & Sig. \\
\hline Total protein (g/dl) & $7.3 \pm 0.49^{\mathrm{b}}$ & $7.6 \pm 0.41^{\mathrm{ab}}$ & $8.0 \pm 0.67^{\mathrm{a}}$ & $7.4 \pm 0.53^{\mathrm{b}}$ & $*$ \\
Albumin (g/dl) & $3.9 \pm 0.19$ & $3.7 \pm 0.29$ & $4.1 \pm 0.31$ & $4.3 \pm 0.23$ & N.S \\
Globulins(g/dl) & $3.4 \pm 0.16$ & $3.9 \pm 0.20$ & $3.9 \pm 0.22$ & $3.1 \pm 0.19$ & N.S \\
Urea (mg /dl) & $24.1 \pm 1.32$ & $28.6 \pm 1.19$ & $21.9 \pm 1.43$ & $26.04 \pm 1.27$ & N.S \\
Creatinin (mg /dl) & $1.3 \pm 0.09$ & $1.4 \pm 0.04$ & $1.1 \pm 0.07$ & $1.5 \pm 0.05$ & N.S \\
T.Cholesterol (mg /dl) & $78.2 \pm 5.19^{\mathrm{a}}$ & $71.8 \pm 7.22^{\mathrm{b}}$ & $80.5 \pm 6.12^{\mathrm{a}}$ & $76.1 \pm 7.32^{\mathrm{a}}$ & $*$ \\
Triglycerides (mg/dl) & $103.9 \pm 12.1^{\mathrm{a}}$ & $88.4 \pm 8.7^{\mathrm{b}}$ & $98.9 \pm 9.2^{\mathrm{a}}$ & $94.7 \pm 10.8^{\mathrm{a}}$ & $* *$ \\
AST (U/L) & $32.9 \pm 2.15$ & $33.5 \pm 2.90$ & $31.1 \pm 3.27$ & $34.3 \pm 2.95$ & N.S \\
ALT(U/L) & $19.7 \pm 1.77^{\mathrm{a}}$ & $20.9 \pm 1.81^{\mathrm{a}}$ & $18.4 \pm 1.47^{\mathrm{b}}$ & $20.5 \pm 1.65^{\mathrm{a}}$ & $*$ \\
Blood picture & & & & & \\
RBcs count & $6.7 \pm 0.29$ & $5.5 \pm 0.21$ & $6.3 \pm 0.32$ & $5.8 \pm 0.17$ & N.S \\
WBcs & $7.2 \pm 1.43$ & $7.0 \pm 1.28$ & $6.8 \pm 1.71$ & $7.4 \pm 1.25$ & N.S \\
HB \% & $8.9 \pm 0.39$ & $9.1 \pm 0.27$ & $8.6 \pm 0.31$ & $8.4 \pm 0.41$ & N.S \\
MCV \% & $55.6 \pm 0.15$ & $52.9 \pm 0.16$ & $59.2 \pm 0.14$ & $50.7 \pm 0.19$ & N.S \\
MCH \% & $19.9 \pm 1.56$ & $18.5 \pm 1.98$ & $18.8 \pm 1.84$ & $19.1 \pm 1.62$ & N.S \\
\hline
\end{tabular}

$\mathrm{N} \mathrm{S}=$ not significant, $*(\mathrm{p}<0.05)$ and $* *(\mathrm{p}<0.01)$. Means in the same row bearing different letters , differ significantly $(\mathrm{p}<$ $0.05)$.

\section{References}

Abdel-Hamid, E. A. (1994): Effect of Adrenal Hormones and Ascorbic Acid on Resistance of Growing Rabbits. Ph. D. Thesis, Fac. Agric. Alex. Univ.

Abdel-Hamid, E. A. and El-Adawy, M. M. (1999): Growth and physiological performance of New Zealand White rabbits feed diet supplemented with Ascorbic Acid. Egypt. Poult. Sci. J. 19 (IV) 857.

Abdel-Monem, U. M. (2000): Dietary supplementation with ascorbic acid and its effects on productive and reproductive performance of New Zealand white rabbits, under the summer condition of Egypt. $2^{\text {nd }}$ International Conference On Animal Production and Health in Semi-Arid Areas. Al-Arish, South Sinai, Egypt. 319-327.

Afify, O. S. and Makled, M. N. (1995): Effect of ascorbic acid on productive and reproductive performance of bouscat rabbits exposed to heat stress First Egyptian Hungarian Poultry Conference, 17-19 September, Alexandria, Egypt: 236-241.

Anderson, R. A. (1987): Chromium, In. W. Mert Z.(Ed) Trace Elements in Human and Animal Nutrition. Vol.1.225244, Academic Press, New York, USA.
Asli, M. M.; Hosseini, S. A.; Lotfallahian, H. and Shariatmadari, F. (2007): Effect of probiotics, yeast, vitamin $\mathrm{E}$ and vitamin $\mathrm{C}$ supplements on performance and immune response of laying hen during high environmental temperature. International Journal of Poultry Science 6(12): 895.

Bord, J. and Sirota, J. H. (1948): Determination of serum creatinine. J. Clin. Invest. 27: 645.

Borel J. S.; Majerus, T. C.; Polansky, M. M.; Moser, P. B. and Andrson, R. A. (1984): Influence of chromium piclonate on glucose usage and metabolic criteria in growing Holstein Calves. J. Anim. Sci., 72: 1591.

Boyd, S. G.; Boon, B. E.; Smith, A. R.; Conner, J. and Dohm, G.I. (1998): Combined diatery chromium piclonate supplementation and e- xercise program leads to a reduct- ion of serum cholesterol and insulin in collegeaged -subject. J. Nutrition biochem.,9: 471-475.

Campbell, W.W.; Beard, J. L.; Joseph, L. J.; Davery, S. L. and Evans, W. J. (1997): Chromium piclonate supplementation and resistive training by older men: Effect on iron status and haematologic indices. Am. J. Clin. Nutr., 66(4) 944 - 949. 
Chang, X. and Mowat, D. N. (1992): Supplemental chromium for stressed and growing feeder calves. J. Anim. Sci., 70: 559-565

Coates, M. E. (1984). Metabolic role of the vitamins, in: physiology and biochemistry of the domestic fowl. Freeman, B.W. (Ed.) Vol. 1, pp.459- 471(London, Academic Press).

Duncan, D.B. (1955): Multiple range and multiple F-test. Biometric- s, 11: 1-42

Doumos, B.T.; Watson, W. A. and Biggs, H. S. (1971): Albumin standards and measurement of serum albumin with bormocresol green. Clin. Chem. Acta, 31: 87.

Eggstein, M. and Kuhlmann, E. (1974): Methods of Enzymatic Analysis. H. U. Bergmeyer Ed., Academic Press, p. 1830 .

El-Gharably, H. J. H. (2000): Some hormonal and biochemical changes in response to chromium in goat. M.Sc. thesis, Faculty of Veterinary, Zagazig University, Egypt.

El-Masry, K. A.; El-Fouly, H. A. and Gabr, S. A. (2001): Physiological action of chromium on some blood biochemical constituents and immune response in relation to growth performance of heat stressed calves. Proceeding of the Scientific Conference on Animal Nutrition., 4: 453-459.

Fawcett, J. K. and Scott, J. E. (1960): A rapid and precise method for the determination of urea. J. Clin. Pathol. 13: 156159

Gaber, F. El. S. and Abdel-Monem, U.M. (2003): Effect of chromium piclonate supplementation on growth performance, carcass traits, biochemical parameters and blood constituents of growth rabbits under the summer Egyptian conditions. Seuz Canal Vet. Med. J. VI (1): 23-32.

Johnson, A. L. (1986): Serum concentrations of prolactin, thyroxin and triiodothyronine relative to season and oestrus cycle in the mare. J. Anim. Sci., 62:1012-1020

Kamal, T. H.; Habeeb, A. A.; Abdel-Samee, A. M. and Abdel-Razik, M. A. (1989): Supplementation of heatstressed Friesian cows with urea and mineral mixture and its effect on the milk production in subtropics .Proceeding of International Symposium on the Constraints and Possibilities of Ruminant Production in the Dry Subtropics, Cairo, Egypt, 1: 183 .

Kegley, E.B.; Spears, J. W. and Brown, T.T. J. (1997): Effect of shipping and chromium supplementation on performance, immune responses and disease resistance of steers. J Anim. Sci., 75: 1956 - 1964

Kornegay, E. T.; Wang, Z.; Wood, C. M. and Lindemann, M. D. (1997): Supplemental Chromium piclonate. Influence nitrogen balance, dry matter digestibility and carcass traits in growing finishing pigs. J. Anim. Sci., 75: 1319.

Lee, N. A. and Reasners, C. A. (1994): Beneficial effect of chromium supplementation on serum triglycerides level in NIDDM. Diabetes Care, 17 (12): 1449-1452.

Marai, I. F. M.; Askar, A. A. and Bahgat, L. B. (2006): Tolerance of New Zealand and Californian doe rabbits at first parity to the sub-tropical environment of Egypt. Livestock Production Science, 104: 165.

McCarty, F., (1991): The case of supplemental chromium and survey of clinical studies with Chromium piclonate. J. AppL. Nutr., 43(1): 58- 66.
Moonsie-Shageer, S. and Mowat, D. N. (1993): Effect of level of supplemental chromium on performance, serum constituents and immune status of stressed feeder ca- lves. J. Anim. Sci., 71: 232- 238

Mowat, D. N.; Chang, X. and Yang, W. Z. (1993): Chelated Chromium for stressed feeder calves. Can. J. Anim. Sci., 73:49-55.

NRC (1981): Nutrient Requirements of Domestic Animals. National Research Council. 5-, Nutrient Requirements of Sheep. $5^{\text {th }}$ Ed. National Academy of Science Washington DC. USA.

Okada, S.; Ohba, H. and Taniyama, M. (1981): Alternation in ribonucleic acid synthesis by chromium. J. Inorg. Biochem., 15: 223.

Page, T. G.; Southern, L. L.; Ward, T. L. and Thompson, D. L. J. (1993): Effect of Chromium piclonate on growth and serum and carcass traits of growing -finishing pigs. J. Anim. Sci., 71: 656-662.

Pion, S. J.; Heugten E.; Van, See M. T., Larick, D. K. and Pardue S. (2004): Effects of vitamin $C$ supplementation on plasma ascorbic acid and oxalate concentrations and meat quality in swine. J. Anim. Sci. 82: 2012

Press, R. L.; Geller, J. and Evans, G. W. (1990): The effect of Chromium piclonate on serum cholesterol and apolipoprotein fractions in human subjects, West. J. Med., 152: 41-45.

Reitman, S. and Frankel, S. (1957): Colorimetric estimation of serum transaminases. Am. J. Clin. Pathol. 28: 56

Richmond, W. (1973): Enzymatic determination of cholesterol.Clin., Chem., 19:1350-1356.Sahina, K.; Sahinb, N. and Kucuk, O. (2003): Effects of chromium, and ascorbic acid supplementation on growth, carcass traits, serum metabolites, and antioxidant status of broiler chickens reared at a high ambient temperature $\left(32^{\circ} \mathrm{C}\right)$. J. Nutr. Res. 23(2) 225. Shahin, K. and Kucuk, O. (2001): Effect of vitamin C and vitamin $\mathrm{E}$ on performance, digestion of nutrients and carcass characteristics of Japanese quails reared under chronic heat stress $\left(34^{\circ} \mathrm{C}\right)$. J. Anim. Physiol. Anim. Nutr. 85 (11-12) 335341

Snedecor, G. W. and Cochran, W.G. (1982): "Statistical Methods." $6^{\text {th }}$ Ed., the Iowa State University Press, Ames, U.S.A.

Tahan, A. A.; Moawd, R. I.; AbdEl-Hamid,A. A. and ElGendy, K. M. (2005): Effect of chromium piclonate supplementation on productive performance of lactating cows. Egyptian Journal of Nutrition and feeds, 8 (1) Special Issue: $555-565$.

Underwood, E.J. (1977): Trace Elements in Human and Animal Nutrition $4^{\text {th }}$ Ed. Acad. Press. Inc., New York.

Verde, M. T. and Piquer, J. G. (1986): Effect of stress on the corticosteroid and ascorbic acid (vitamin C) content of the blood plasma of rabbits. J. Appl. Rabbit Res. 9: 181.

Weichselbaum, T. E. (1946): A biuret colorimetric method for determination of total protein. Am. J. Clin. Path. Tech. Sect. 10: 40

Weser, U. and Koolman, J. (1969): Reactivity of some transition metals on nuclear protein biosynthesis in rate liver. Experientia, 26:246. 
تأثير إضافة بيكلونات الكروميوم و / أو حامض الأسكوربيك علي أداء النمو وصفات الأبيحة وبعض قياسات الدم

$$
\text { وصورة الدم في الجداء النامية تحت ظروف الصيف }
$$

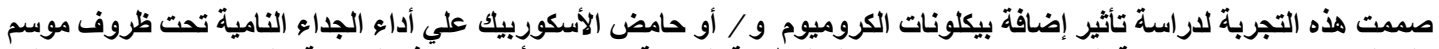

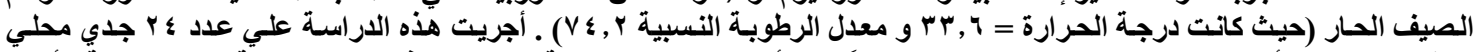

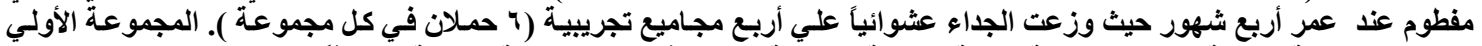

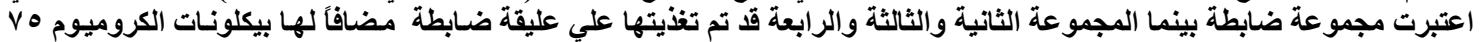

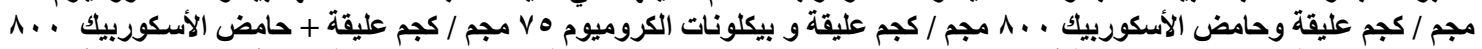

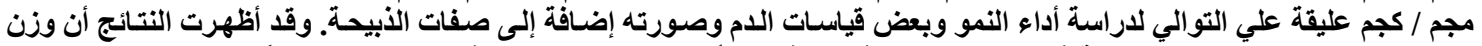

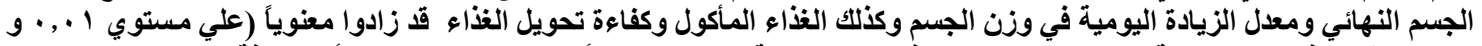

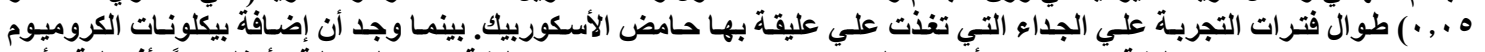

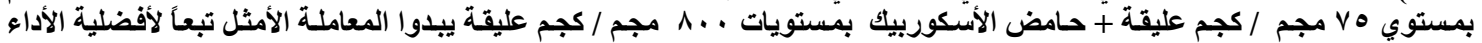

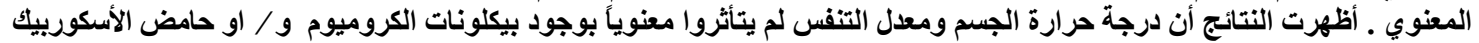

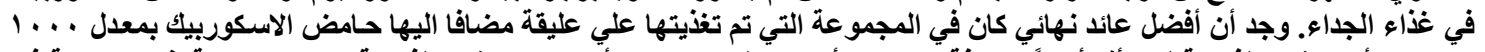

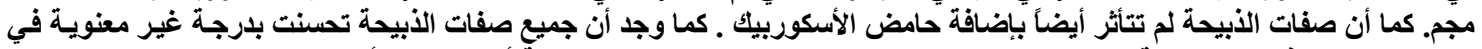

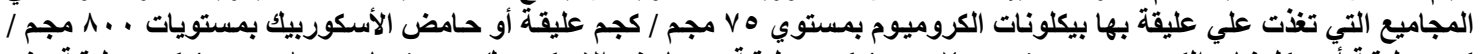

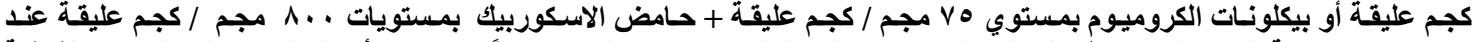

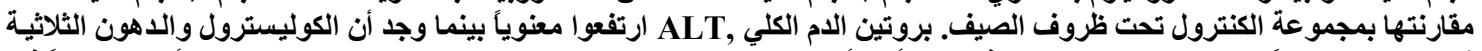

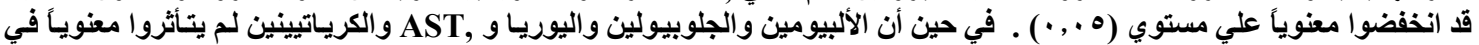

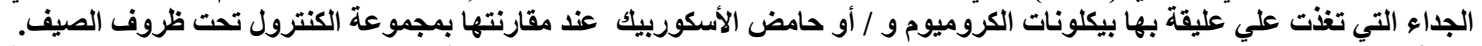

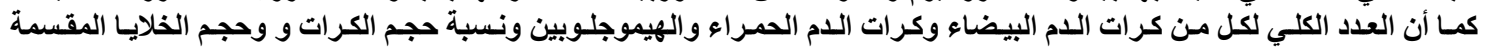

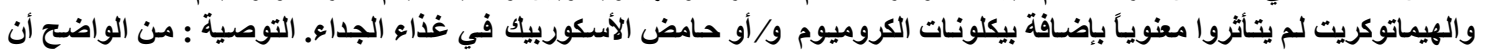

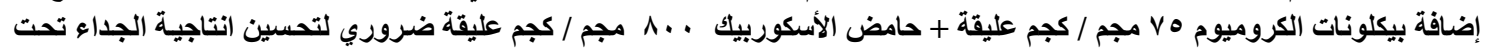
ظروف الصيف الحار. 